\title{
MACRO- AND MICROMORPHOLOGY OF SANCHEZIA NOBILIS HOOK. CULTIVATED IN EGYPT: LEAF, STEM AND FLOWER
}

Ahmed E. Abd-Ellah ${ }^{1}$, Khaled M. Mohamed ${ }^{2}$, Enaam Y. Backheet ${ }^{2}$ and Mahmoud H. Mohamed ${ }^{1}$

${ }^{1}$ Department of Pharmacognosy, Faculty of Pharmacy, Al-Azhar University, Assiut, Egypt

${ }^{2}$ Department of Pharmacognosy, Faculty of Pharmacy, Assiut University, Assiut, Egypt

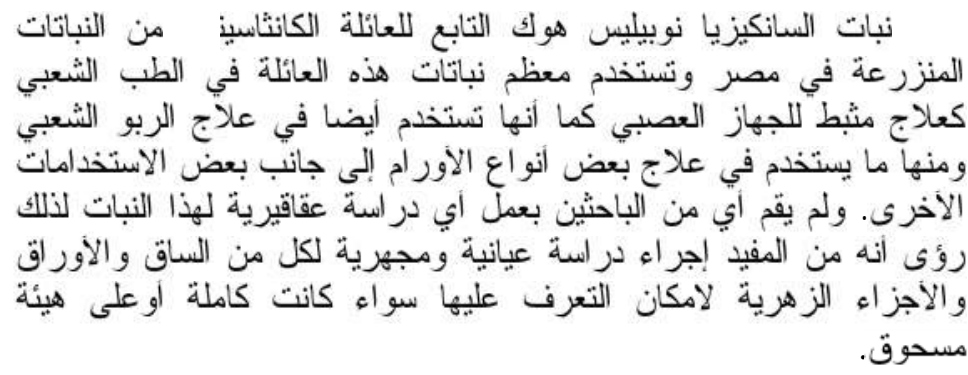

The detailed macro- and micromorphological characters of the leaf stem and flower of Sanchezia nobilis Hook. were studied with the aim to find out the diagnostic elements of these organs, which facilitate their identification in both entire and powdered forms.

\section{INTRODUCTION}

The genus Sanchezia (Family Acanthaceae) comprises 20 species of tropical and subtropical regions of the world. The plants of this genus are distributed in Mediterranean regions, India, Ceylon, Malay, Africa, Australia and U.S.A. Most of them are perennial from tropical rainforest in central and South America (Ecuador). ${ }^{1-3}$ The leaves have an opposite decussate phyllotaxis. The main trunk bears terminal or axillary spikes of tubular, yellow, orange, red or purple flowers. The shrub can be grown as a house plant, if high air humidity is available.

Family Acanthaceae is of considerable economic and medicinal

Received in 17/5/2006 \& Accepted in 20/11/2006 
values. A decoction of Acanthus with cumin is given in dyspepsia with acid eructation. ${ }^{3}$ The leaves of Justicia are used as an emollient in rheumatism and neuralgia. ${ }^{3 \& 4}$ Also, they are useful in bronchitis, leprosy, heart troubles, thirst, asthma, fever, vomiting, loss of memory, lucoderma, jaundice and tumors. The leaves of Ruellia are diuretic, useful in bronchitis, asthma, sore eyes, fever and gonorrhea. $3 \& 4$

The available current literature deals with the isolation of iridoids, phenylpropanoids, phenylethanoids, flavonoids, lignans, neolignans, triterpenoides and sterols. ${ }^{5-7}$ These classes of active constituents have diverse biological activities and medicinal values.

Reviewing the available current literature, no detailed information could be traced concerning the macro- and micromorphology of the different organs of the plant, as well as no reports concerning phytochemical and biological studies. This initiated our interest to study this plant. Accordingly, this work describes the macro- and micromorphological characters of the leaf, stem, petiole and flower of Sanchezia nobilis Hook.

\section{MATERIAL}

The plant material used for this study consists of Sanchezia nobilis Hook. herb. obtained from Aswan botanical garden where it is cultivated and authenticated in the botanical garden index. The plant was collected in February and March 2003 before the flowering stage, which occurs during May. ${ }^{8 \& 9}$ The plant was identified by Dr. Gamal Abd - El Hafize, Associate professor of Horticulture, Faculty of Agriculture, Assuit University; the herbarium was kept in the department of pharmacognosy, Al-Azhar University, Assuit. Fresh samples of Sanchezia nobilis Hook. leaf, stem and inflorescence were preserved in a mixture of $70 \%$ alcohol-glycerinwater (1:1:1) for cutting sections in the different organs of the plant. Each organ of the plant material was airdried and reduced to powder of suitable particle size and kept for microscopical investigation.

\section{Habitat}

Sanchezia nobilis Hook. (Fig. 1) is a subshrub or an erect, low-branched shrub perennial and cultivated in tropical regions of the Central and South America. ${ }^{1-3}$ It reaches about 0.5-1.5 meter height. The leaves are simple, ovate to lanceolate and of an opposite decussate phyllotaxis. They are dark green in the upper surfaces and pale green in the lower ones. The vennation is pinnate-reticulate. The leaves are petiolated with nearly cylindrical outline. The flowers are hermaphrodite, greenish, with faint characteristic odour, borne in a compound spike racemose inflorescence. The flower buds begin to appear in the beginning of May and open at its end. 


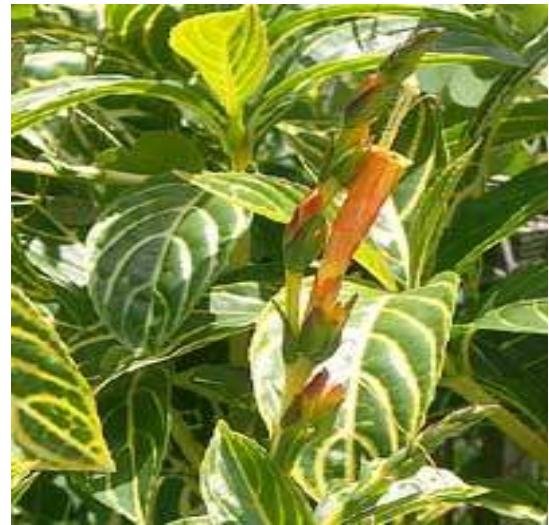

Fig. 1: Photo of Sanchezia nobilis Hook.

$$
\text { X } 1 / 4
$$

\section{A) THE LEAF}

\section{Macromorphological study of the leaf and the petiole (Fig. 2)}

The leaf of Sanchezia nobilis Hook. is simple, ovate to lanceolate, exstipulate varies in shape and size with slightly dentate margin, asymmetric base and acute to acuminate apex with an opposite decussate phyllotaxis. It has a dark green upper surface and a paler lower one, with faint characteristic odour. The vennation is pinnate-reticulate. The midrib and lateral veins are more prominent on the lower surface. The upper surface is dark green in colour, while the lower surface being paler; the texture is glossy on both surfaces. The leaf measures $7-9 \mathrm{~cm}$ in length and $4-6 \mathrm{~cm}$ in width. The leaves are petiolated with a nearly cylindrical to subcylindrical, green in colour petioles having very small hairs. Generally, the upper leaves have shorter petioles than the lower ones. They measure $1.5-2 \mathrm{~cm}$ in length and 2-3 $\mathrm{mm}$ in diameter.

\section{Micromorphological study of the leaf (Fig. 3A\&B)}

The transverse section in the lamina through the midrib region (Fig. 3A) appears more or less slightly bi-convex in outline. It consists of upper and lower epidermises enclosing inbetween a dorsiventral mesophyll, which is interrupted in the midrib region by the main vascular bundle and the cortical tissue, in addition to several small lateral vasocentric bundles at the small veins. The mesophyll is differentiated into an upper palisade and spongy tissue. The palisade tissue consists of one row of columnar cells in the lamina region and of two rows towards the midrib. The cells of the first row are much larger than those of the second one.

\section{The upper epidermis (Fig. 4A)}

The upper epidermis in the transverse section is formed of one row of isodiametric to subrectangular thin-walled cells covered with thick smooth cuticle; while in surface view (Fig. 4A) they are polygonal, subrectangular and rarely isodiametric with straight anticlinal walls and covered with thin smooth cuticle. The cells measure (20-26-28) $\mu$ in length, (7-10-12.5) $\mu$ in width and (11-13-15) $\mu$ in height. They carry two types of hairs one of them is the commonly occurring nonglandular, uniserriate, unicellular and multicellular hairs measuring (50-60-68) $\mu$ in length and (7-10-12) $\mu$ in width, and the other is the rarely occurring glandular hairs of small, short, unicellular stalk, multicellular head mainly of 4-6 cells 


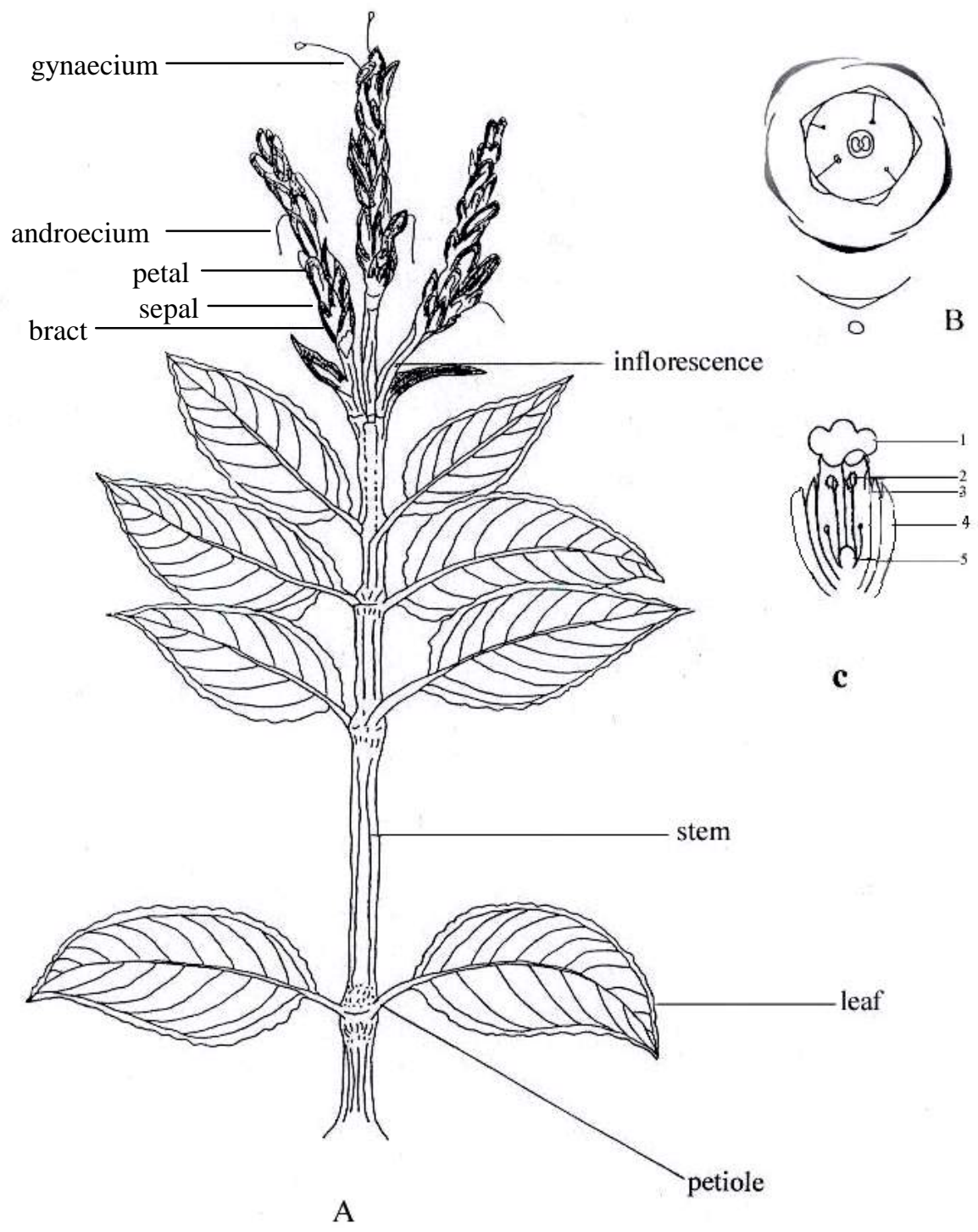

Fig. 2:

A) Morphology of the leaf, petiole, stem and flower

B) Transverse cut in the flower

X 3

C) Longitudinal cut in the flower

$\mathrm{X} 2$

1-Corolla 2-Androecium

3- Calyx 4- Bract 5- Ovary 

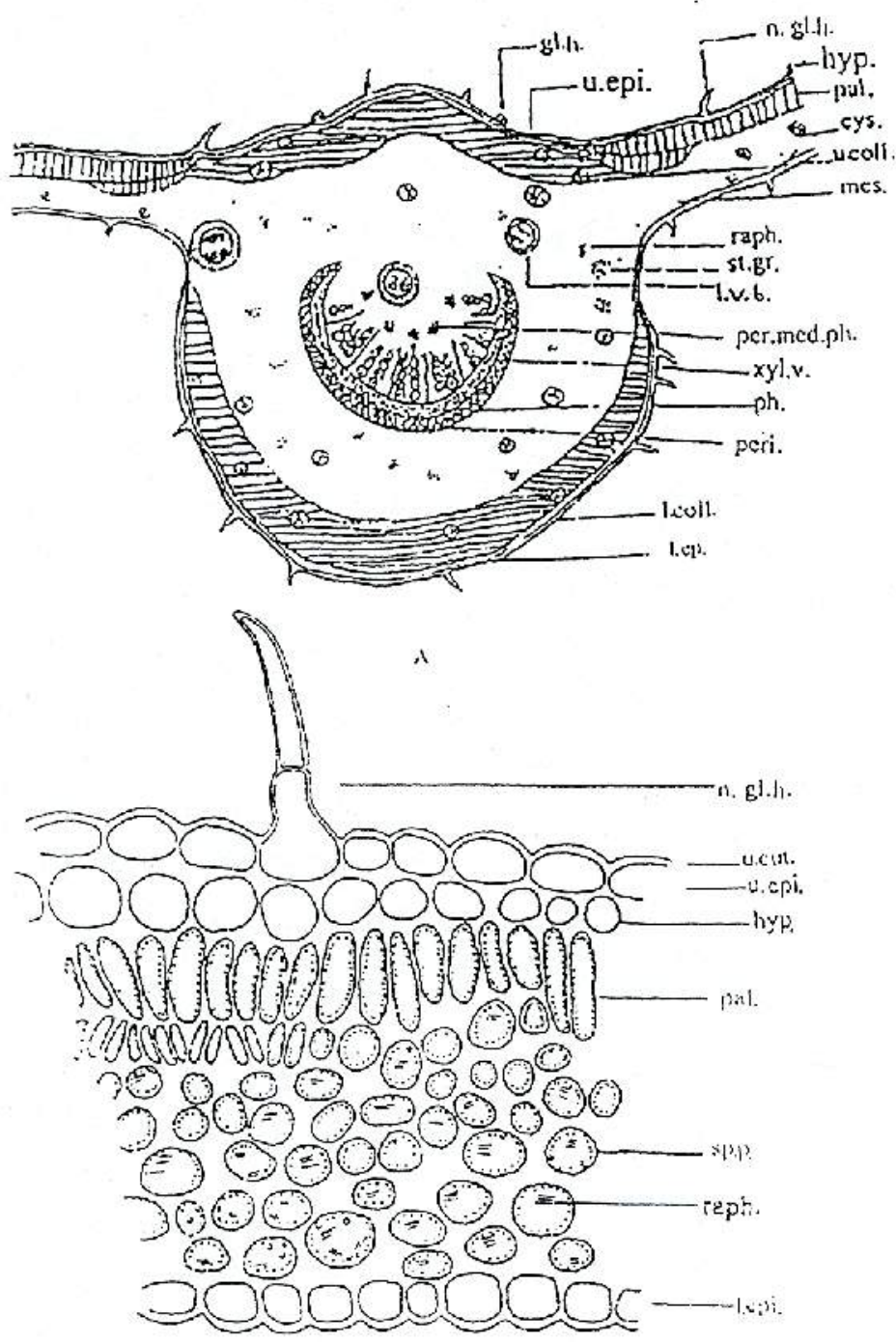

Fig. 3:

A) Diagrammatic T.S. in the leaf

$€ 125$

B) Detailed T. S. in the lamina

$€ 125$

cys.; cystolithes of calcium carbonate. gl.h.; glandular hair. hyp.; hypodermis. 1.coll.; lower collenchyma. 1.cut.; lower cuticle. 1.epi.; lower epidermis. l.vas.b.; lateral vascular bundle. mes.; mesophyll. n.gl.h.; nonglandular hair. pal.; palisades. par.; parenchyma. peri.; pericycle. per.med.ph.; perimedullary phloem. ph.; phloem. ph.f.; phloem fiber. raph.; raphides of calcium oxalate. sp.par.; spongy parenchyma. st.gr.; starch granules. u.cut.; upper cuticle. u.coll.; upper collenchyma. u.epi.; upper epidermis. w.p.; wood parenchyma. x.v.; xylem vessel. 

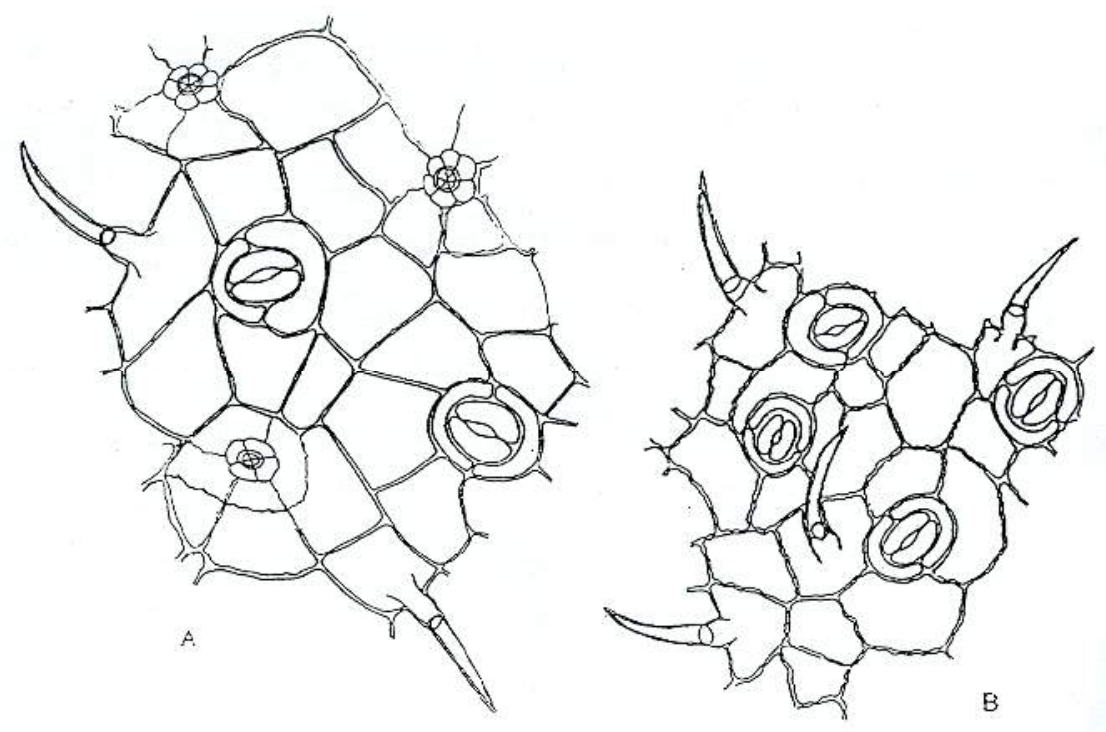

Fig. 4:

A) Surface preparation of the upper epidermis B) Surface preparation of the lower epidermis

$$
\begin{aligned}
& € 468.75 \\
& € 468.75
\end{aligned}
$$

embedded in the upper neural epidermal cells and on the adjacent cells of the intercostal regions. They are covered with thin smooth cuticle measuring (52-58-62) $\mu$ in the width. Stomata are of the diacytic type, measuring (45-52-58) $\mu$ in diameter. The upper epidermis is accompanied by one row of hypodermis measuring (28-34-40) $\mu$ in length, (15-22-35) $\mu$ in width and (12-18-24) $\mu$ in height.

\section{The lower epidermis (Fig. 4B)}

The lower epidermis in the transverse section consists of one row of polygonal cells with sinuous anticlinal walls, covered with thick smooth cuticle and measure (21-2427) - in length, (6-8-10) - in width, and (9-11-13) - in height. The nonglandular trichomes and the diacytic stomata are present resembling those of the upper epidermis, but they are of greater number.

\section{The cortical tissue (Fig. 5)}

The cortical tissue of the midrib region is represented by a mass of collenchymatous cells, formed of 7-9 rows of nearly rounded cells measuring (15-28-40) $\mu$ in length, (7$\underline{15}-22) \mu$ in width and (4-7-10) $\mu$ in diameter followed by a mass of parenchyma cells of about 6-8 rows, measuring (22-38-52) $\mu$ in length, (916-26) $\mu$ in width and (8-14-18) $\mu$ in diameter. Some of these cells contain starch granules measuring (4- $\underline{6}-11) \mu$ in diameter as well as raphids of calcium oxalate measuring (6-10-14) $\mu$ in length. There are numerous cells, which are modified to cystolithes 

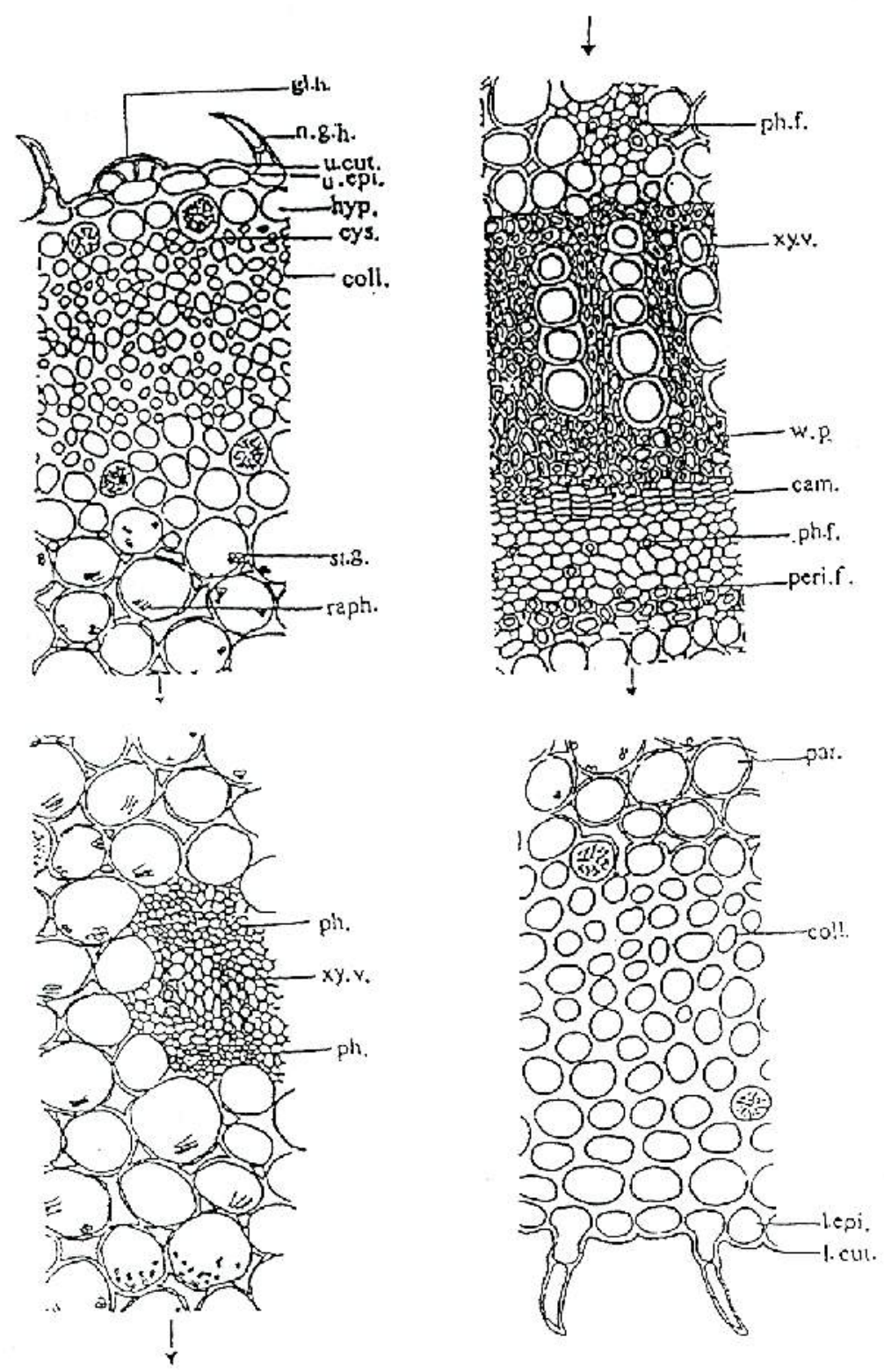

Fig. 5: Detailed T.S. in the midrib region of the leaf

$€ 125$

cam.; cambium. coll.; collenchyma. cys.; cystolithes of calcium carbonate. gl.h.; glandular hair. hyp.; hypodermis. 1.coll.; lower collenchyma. 1.cut.; lower cuticle. 1.epi.; lower epidermis. n.gl.h.; nonglandular hair. par.; parenchyma. peri.; pericycle. peri.f.; pericyclic fiber. ph.; phloem. ph.f.; phloem fiber. raph.; raphides of calcium oxalate. st.gr.; starch granules. u.cut.; upper cuticle. u.coll.; upper collenchyma. u.epi.; upper epidermis. w.p.; wood parenchyma. x.v.; xylem vessel. 
containing deposits of calcium carbonate measuring (17-20-24) $\mu$ in diameter and (80-120-150) $\mu$ in length. The occurrence of these cystolithes is recorded as one of the most characteristic features of family Acanthaceae. ${ }^{9}$ In addition, there are numerous scattered vasocentric additive vascular bundles.

\section{The perimedullary phloem}

There are newly formed small patches of phloem elements on the periphery of the pith, named ,Perimedullary or interxyllary phloem $f$, which is one of the peculiarities of family Acanthaceae. ${ }^{9 \& 10}$

\section{The vascular system}

It is represented by a large central collateral bundle in addition to several vasocentric vascular bundles of variable size scattered in the cortical region.

\section{The xylem}

The xylem region consists of radial rows of lignified spiral and annular vessels, tracheids and wood parenchyma. The xylem vessels measure (15-25-36) - in diameter, while tracheids have blunt ends and showing lignified thickened walls, they measure (100-160-190) • in length, and (23-38-42) - in width. The wood parenchyma consists of rectangular to subrectangular cells with lignified narrow walls and wide lumina, measuring (68-72-74) • in length and (15-18-22) - in width. The xylem vessels are traversed by bi- to tetraseriate rectangular medullary rays.

\section{The cambium}

The cambium is formed of 2-3 rows of thin-walled, subrectangular, tangentially elongated and radially arranged cells.

\section{The phloem}

The phloem is formed of a zone of soft shining thin-walled elements of sieve tissue and few phloem fibers. The phloem fibers are of moderately thick, slightly lignified walls, comparatively narrow lumina and acute apices, measuring (270-400440) - in length and (8-20-28) in diameter.

\section{The pericycle}

The pericycle exhibits more or less a continuous ring of fibers interrupted by few parenchyma cells. These fibers are of moderately thin, slightly lignified walls, comparatively wide lumina and curved apices. They measure (230-360-400) - in length and (7-20-27) in diameter.

\section{B) THE PETIOLE}

\section{Micromorphological study of the petiole (Fig. 6A\&B)}

The transverse section in the petiole appears nearly cup-shaped in outline; it is more or less similar to that of the leaf except for the presence of a layer of an endodermis exhibiting a starch sheath and a casparian thickening which stained blue with Chlor-Zinc-Iodine. ${ }^{9}$ 


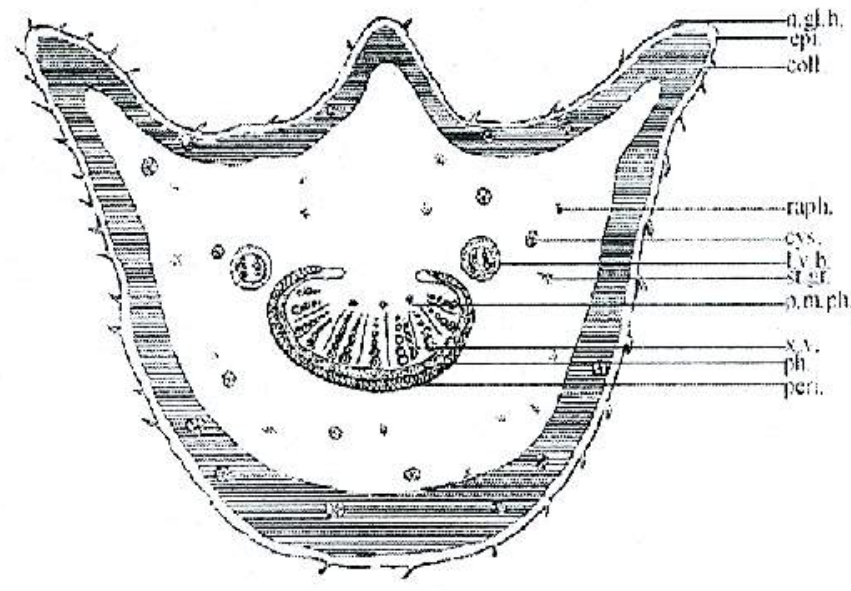

Fig. 6A: Diagrammatic T.S. of the petiole

coll.; collenchyma. cys.; cystolithes of calcium carbonate. epi.; epidermis. n.gl.h.; nonglandular hair. peri.; pericycle. per.med.ph.; perimedullary phloem. ph.; phloem. raph.; raphides of calcium oxalate. st.gr.; starch granules. x.v.; xylem vessel.

\section{The powdered leaf and petiole}

The powdered leaf and petiole (Fig. 7) is pale green in colour, with a faint odour and a slightly bitter taste. It is characterized microscopically by the following features:

1- Fragments of both upper and lower epidermises showing that those of the upper epidermis are polygonal with straight anticlinal walls, covered with smooth cuticle and carry nonglandular hairs mainly of the unicellular type as well as the presence of diacytic stomata, but those of the lower epidermis are polygonal with sinuous anticlinal walls and carry larger number of both hairs and stomata.
2- Numerous scattered cystolithes of calcium carbonate, which are solitary, elongated with irregular walls, striated surfaces and acute ends. These cystolithes dissolve with strong effervescence in dilute $\mathrm{HCl}$.

3- Nonglandular hairs of common occurrence, which are uniseriate mainly unicellular, rarely multicellular in addition to the rarely occurring glandular hairs of unicellular stalk and multicellular head of 4-6 cells.

4- Fragments of pericyclic fibers with slightly thin lignified walls, moderately wide lumina and blunt apices, as well as fragments of phloem fibers with slightly thick lignified walls, moderately narrow lumina and acute apices. 


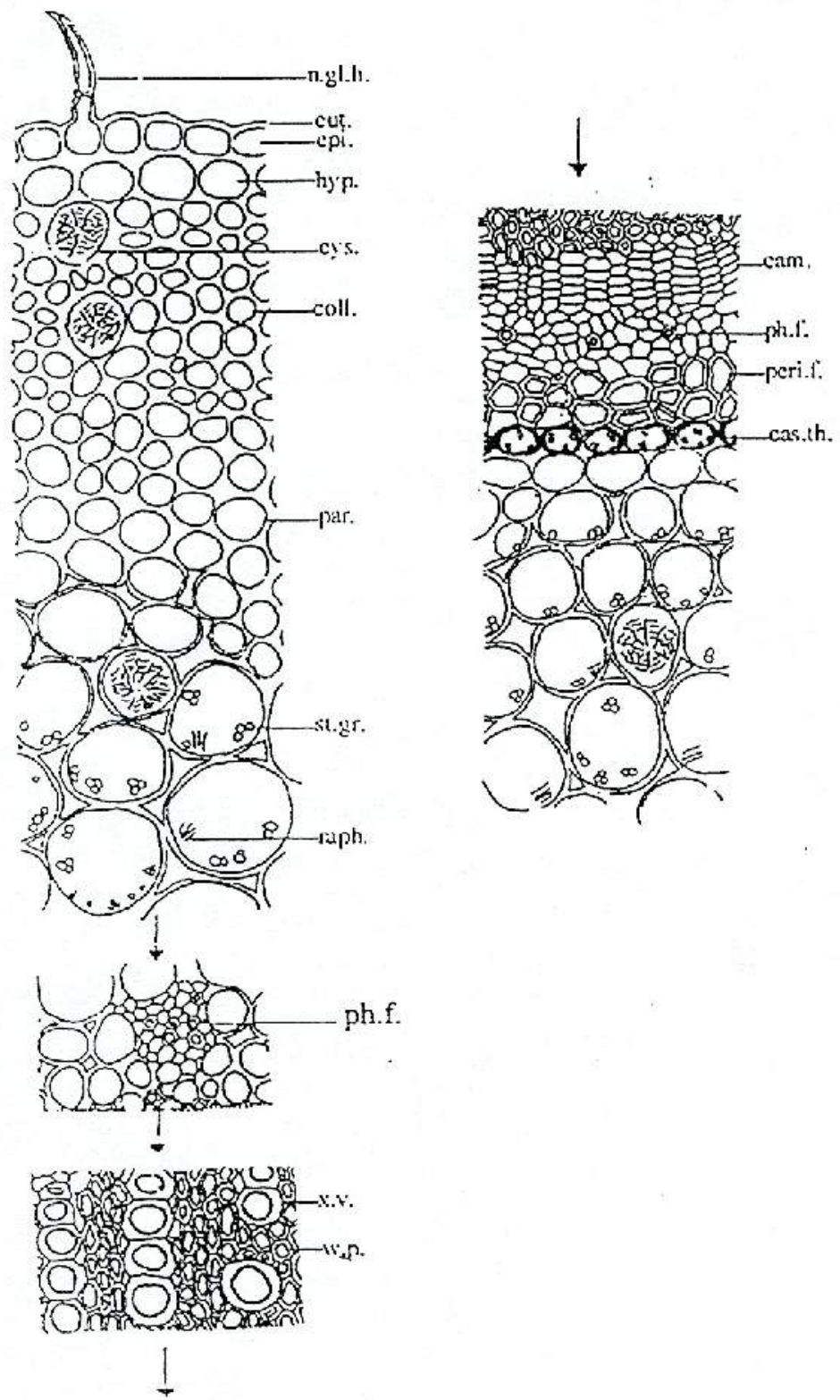

Fig. 6B: Detailed T.S. of the petiole

$€ 250$

cam.; cambium. cas.th.; casparian thickening. coll.; collenchyma. cut.; cuticle. cys.; cystolithes of calcium carbonate. epi.; epidermis. hyp.; hypodermis. n.gl.h.; nonglandular hair. par.; parenchyma. peri.f.; pericyclic fiber. ph.f.; phloem fiber. raph.; raphides of calcium oxalate. st.gr.; starch granules. w.p.; wood parenchyma. x.v.; xylem vessel. 


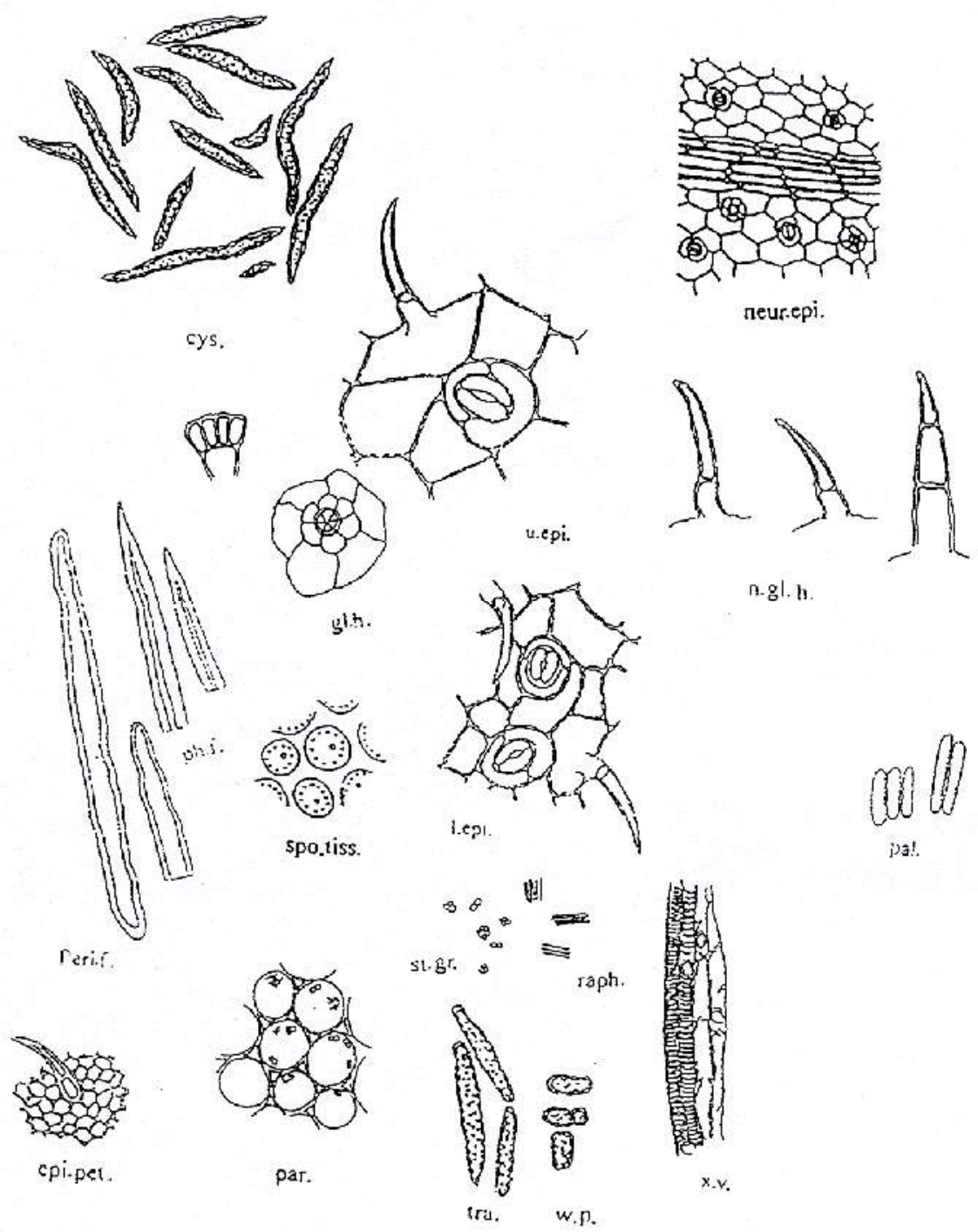

Fig. 7: The powdered leaf and petiole

cys.; cystolithes of calcium carbonate. epi.pet.; epidermis of the petiole. gl.h.; glandular hair. neur.epi..; neural epidermis. n.gl.h.; nonglandular hair. pal.; palisade. par.; parenchyma. peri.f.; pericyclic fiber. ph.f.; phloem fiber. raph.; raphides of calcium oxalate. spo.tiss.; spongy tissue. tra.; tracheids. st.gr.; starch granules. w.p.; wood parenchyma. x.v.; xylem vessel. 
5- Abundant scattered raphides of calcium oxalate in addition to numerous scattered starch granules mainly of the compound type, oval in shape with indistinct hilum and indistinct striations.

6- Fragments of lignified xylem vessels showing spiral and annular thickenings.

7- Fragments of subrectangular tracheids from the petiole with lignified walls.

8- Fragments of wood parenchyma from the petiole of polygonal isodiammetric subrectangular cells having thick lignified pitted walls.

9- Fragments of the epidermis of the petiole carrying nonglandular unicellular hairs.

10- Fragments of the neural epidermal cells exhibiting that those on the midrib region are polygonal, square to subrectangular, axially elongated with straight anticlinal walls, but those adjacent to them (neighboring the cells of the intercostal region) are more or less isodaimetric.

\section{C) THE STEM}

\section{Macromorphological study of the stem (Fig. 2A)}

The stem of the plant is erect, suffruticose, perennial, round in its upper part and quadrilateral in its lower one. It reaches about 0.5-1 meter in length and $0.5-2 \mathrm{~cm}$ in diameter. It is monopodially branched showing more or less long internodes up to $5 \mathrm{~cm}$ in the lower parts and shorter in the upper ones, breaks with complete fracture.

\section{Micromorphological study of the stem}

f- The young stem (Fig. 8A\&B)

The transverse section in the young stem appears circular in outline with few hairs. In the very young stem, the outer part of the cortex exhibits alternating sectors of both collenchyma and parenchyma, which is considered as one of the peculiarities of family Acanthaceae. ${ }^{9 \& 10}$ It shows an outer epidermis carrying few hairs, followed by one layer of a hypodermis and 6-8 rows of collenchyma followed by a comparatively narrow 5-7 rows of parenchyma. The pericycle is represented by a nearly complete ring of pericyclic fibers interrupted by few parenchyma cells. The pericycle surrounds a complete ring of vascular tissue and wide parenchymatous central pith.

\section{The epidermis}

The epidermis in the transverse section is more or less similar to that of the leaf and petiole, measuring (2232-42) - in length, (8-12-16) • in width and (16-18-22) - in height. Nonglandular hairs of the uniserriate unicellular type are present. No stomata are observed.

\section{The cortex}

The outermost region of the cortex is formed of 6-8 rows of collenchyma cells measuring (12-24-41) $\mu$ in length, (7-12-18) $\mu$ in width and (612-16) $\mu$ in height, followed by $4-6$ 

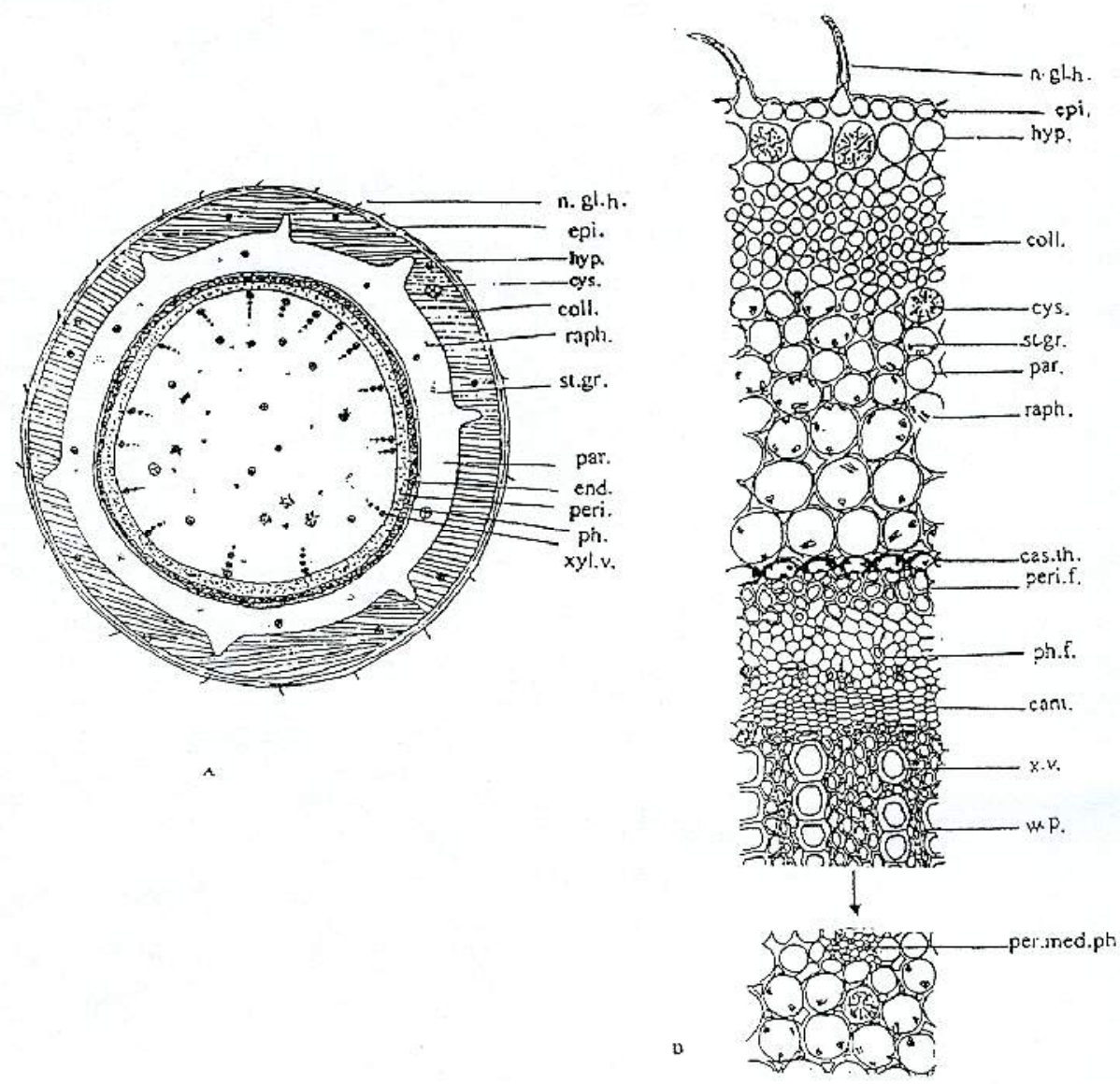

Fig. 8:

A) Diagrammatic T.S. of the young stem

$€ 187.5$

B) Detailed T.S. of the young stem

$€ 187.5$

cam.; cambium. cas.th.; casparian thickening. coll.;collenchyma. cys.;cystolithes of calcium carbonate. epi.;epidermis. end.; endodermis. n.gl.h.; nonglandular hair. par.; parenchyma. peri.; pericycle. peri.f.; pericyclic fiber. per.m.ph.; perimedullary phloem. ph.; phloem. . ph.f; phloem fiber. raph.; raphides of calcium oxalate. st.gr.; starch granules. w.p.; wood parenchyma. x.v.; xylem vessel. 
rows of rounded to oval-shaped parenchyma cells measuring (24-4055) $\mu$ in length, (11-18-28) $\mu$ in width and (10-16-20) $\mu$ in height. Numerous scattered cystolithes of calcium carbonate resembling those present in leaves and petioles in both shape and size are also present.

\section{The endodermis}

It is similar to that of the petiole.

\section{The pericycle}

The pericycle is formed of a continuous ring of fibers interrupted by few polygonal cells.

\section{The vascular system}

The vascular system consists of a continuous ring of phloem, cambium and xylem.

\section{Perimedullary phloem}

There are small patches of phloem elements on the periphery of the pith, resembling those present in the leaves.

\section{The phloem}

It is similar to that of the leaf and petiole.

\section{The cambium}

The cambium is formed of 4-6 rows of thin-walled, subrectangular, tangentially elongated and radially arranged cells.

\section{The xylem}

The xylem consists of a comparatively wide zone of thickwalled lignified elements. The xylem elements include xylem vessels, wood fibers, tracheids and wood parenchyma. The xylem vessels are arranged in radial rows traversed by bi-to tetraseriate lignified medullary rays and showing spiral, pitted and annular thickenings and measure (1728-40) - in diameter. The tracheids have blunt ends and show lignified pitted thickening, they measure (120$\underline{180}-210) \bullet$ in length and (26-42-46) • in width.

\section{The pith}

The pith is formed of a wide central zone of rounded to oval parenchymatous cells containing raphides of calcium oxalate.

\section{II- The old stem (Fig. 8C\&D)}

The transverse section in the old stem is quadrilateral in outline. it is more or less similar to that of the young stem except for the presence of an outer cork layer, where the phellogen originates superficially in the hypodermis region. The cork in the transverse section consists of 5-6 rows of subrectangular, radially arranged and tangentially elongated cells, measuring (44-58-70) $\mu$ in length, (14-20-27) $\mu$ in width and (2428-32) $\mu$ in height.

\section{The powdered stem}

The powdered stem (Fig. 9) is yellowish green in colour, with a bitter taste and a faint characteristic odour. It is characterized microscopically by the following features:

1- Numerous cystolithes of calcium carbonate, irregular in outline with striated surfaces and acute ends. 

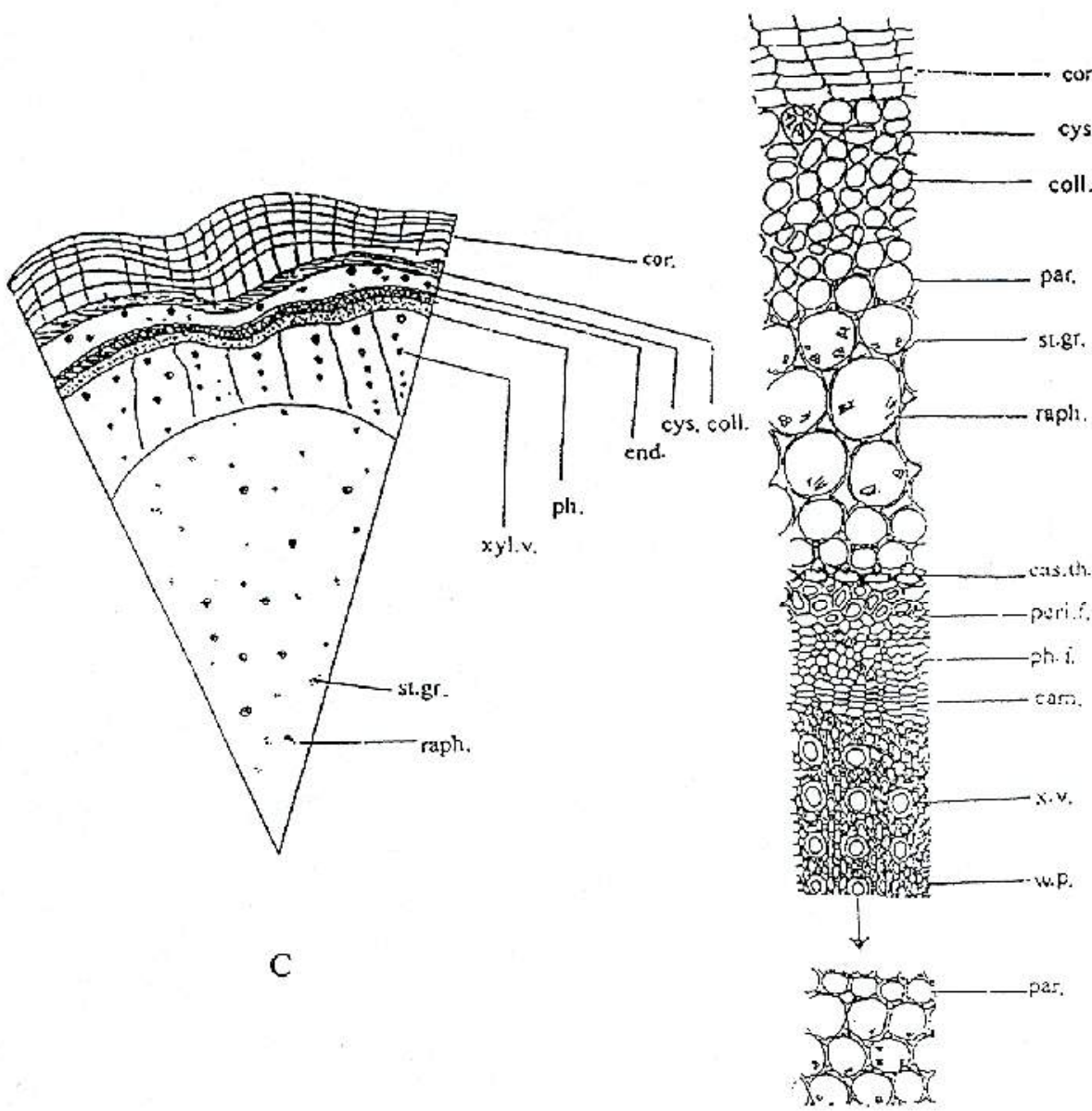

$\mathrm{D}$

Fig. 8:

C) Diagrammatic T.S. of the old stem

$€ 187.5$

D) Detailed T.S. of the old stem

$€ 187.5$

cam.; cambium. cas.th.; casparian thickening. coll.;collenchyma. cys.;cystolithes of calcium carbonate. epi.;epidermis. end.; endodermis. n.gl.h.; nonglandular hair. par.; parenchyma. peri.; pericycle. peri.f.; pericyclic fiber. per.m.ph.; perimedullary phloem. ph.; phloem. . ph.f; phloem fiber. raph.; raphides of calcium oxalate. st.gr.; starch granules. w.p.; wood parenchyma. x.v.; xylem vessel. 


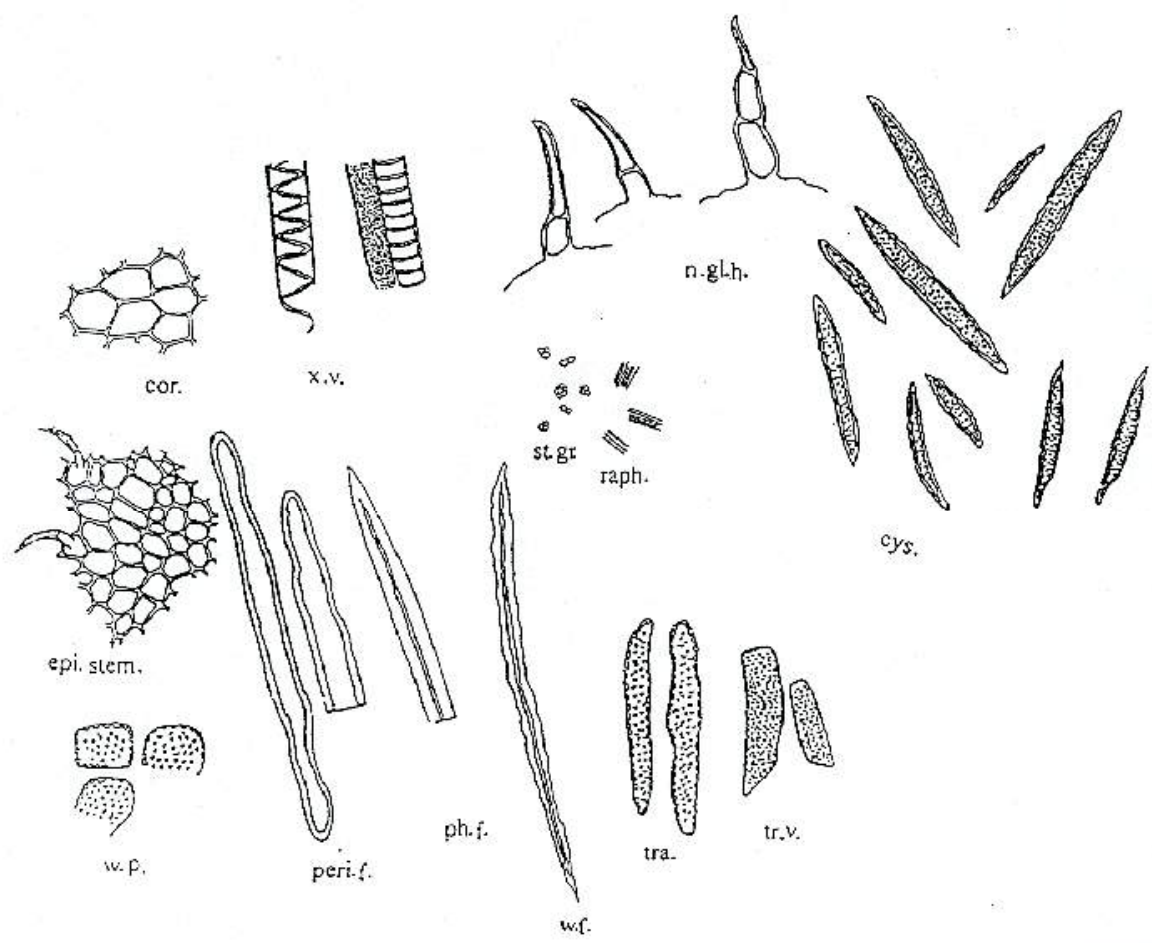

Fig. 9: The powdered stem

cor.; cork. cys.; cystolithes of calcium carbonate. epi.stem.; epidermis of stem. n.gl.h.; nonglandular hair. peri.f.; pericyclic fiber. ph.f.; phloem fiber. raph.; raphides of calcium oxalate. st.gr.; starch granules. tra.; tracheids. tr.v.; tracheidal vessel. w.f.; wood fiber. w.p.; wood parenchyma. x.v.; xylem vessel.

2- Numerous xylem fragments showing pitted, annular, and spiral lignified xylem vessels as well as lignified, pitted tracheids, and lignified wood fibers with thick irregular walls, narrow lumina and acute tapering ends.

3- Fragments of lignified, pitted wood parenchyma.

4- Numerous scattered raphides of calcium oxalates as well as starch granules mainly of the compound type, oval in shape with indistinct hilum and indistinct striations.

5- Fragments of slightly lignified phloem fibers, with thick walls, narrow lumina and acute tapering ends, as well as slightly lignified pericyclic fibers with relatively thin walls, wide lumina and blunt ends.

6- Occasional fragments of polygonal cork cells with yellowish brown content. 


\section{D) THE FLOWER}

Macromorphological study of the flower (Fig. 2A)

Inflorescence

The flowers are arranged in a racemose manner forming a compound spike inflorescence ${ }^{1}$ in which the growth begins from downward to upward. The flowers are hermaphrodite, sessile, small, irregular and zygomorphic. It has a faint characteristic odour, and a slight bitter taste, measuring about 2.5-3.5 $\mathrm{cm}$ in length.

\section{The bract (Fig. 2A)}

It is green in colour, oblong or oblong-lanceolate with acute apex measuring $1.2-1.3 \mathrm{~cm}$ in length and $0.25-0.5 \mathrm{~cm}$ in width.

\section{The calyx (Fig. 2A)}

It is green in colour, consists of five alternating sepals (polysepalous), measuring $1.3-1.5 \mathrm{~cm}$ in length and $0.2-0.4 \mathrm{~cm}$ in diameter, with imbricate aestivation.

\section{The corolla (Fig. 2A)}

It is yellowish orange in colour formed of five united petals (gamopetalous), tubular, hairy outside, formed of five lobes each of two lips, an outer and an inner one. The petals are oblong-obovate, with rounded apices and entire margins. The corolla measures $2.5-3 \mathrm{~cm}$ in length.

\section{The androecium (Fig. 2A)}

It consists of four epipetalous stamens in two sets (didynamous) ${ }^{1}$ two fertile each with oblong twocelled, hairy anthers and two staminodes (tetraandrous). Filaments are of the fertile stamens exerted beyond the corolla tube, and measure $1.3-1.5 \mathrm{~cm}$ in length, those of the staminodes are very short $0.5-0.7 \mathrm{~cm}$ in length. The anther is attached to the filament through "adnate" behavior. The anther opens with an "Introse dehiscence". 1

\section{The gynaecium (Fig. 2A)}

It consists of a bicarpillary, bilocular superior ovary, measuring $0.3-0.4 \mathrm{~cm}$ in length and $0.2-0.3 \mathrm{~cm}$ in diameter, each loculus has two ovules attached to an axial placenta. The style is long and measures 2.5-3 $\mathrm{cm}$ in length and $0.4-0.5 \mathrm{~cm}$ in diameter. The stigma is not branched and papillosed.

\section{The floral formula;}

$\chi, \mathscr{C}^{\prime}, \mathrm{K}_{5}, \widehat{C}_{(5)} \lambda_{4_{(2,2)}}, \mathrm{G}(2)$

Micromorphological study of the flower

The bract

The epidermis (Fig. 10A\&B)

The epidermis of the bract consists of polygonal cells with wavy anticlinal walls in the upper epidermis and straight in the lower epidermis, both epidermises (Fig. 10C\&D) are covered with thin smooth cuticle, the upper epidermal cells measure (2850-64) $\mu$ in length, (20-26-35) $\mu$ in width and (18-25-30) $\mu$ in height, while those of the lower epidermis are larger measuring (26- $\underline{-10}-70) \mu$ in length, (18-25-33) $\mu$ in width and 

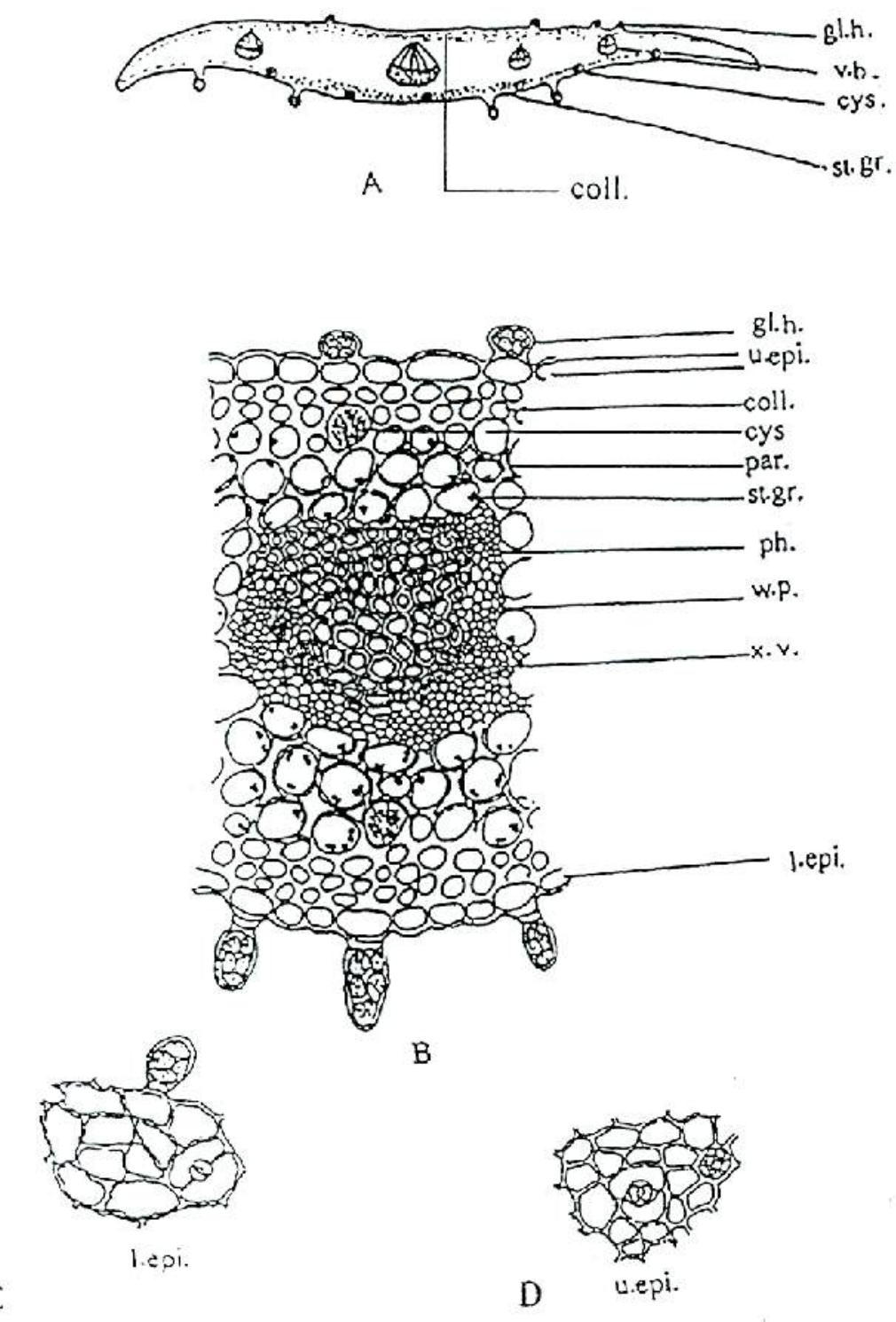

1. epi.

C

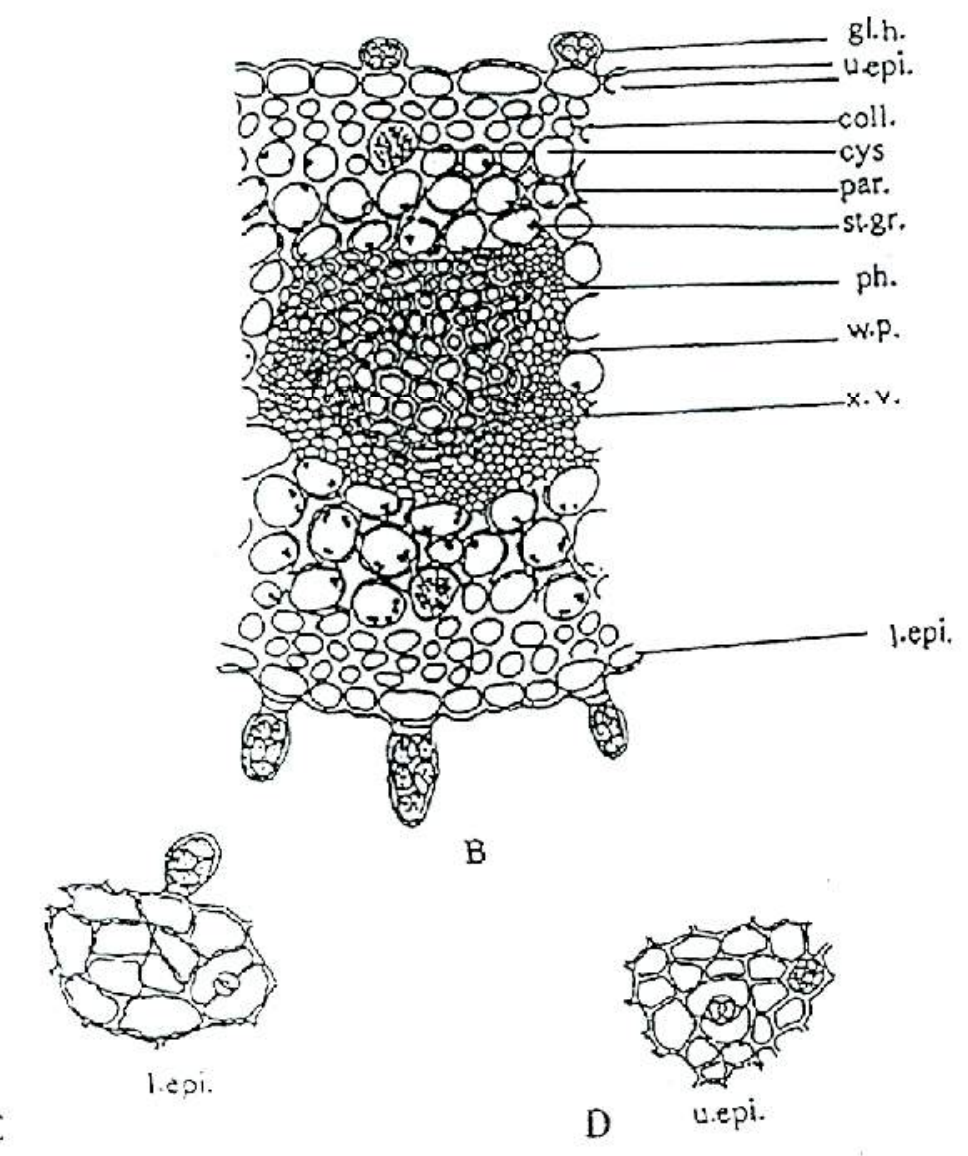

Fig. 10:

A) Diagrammatic T.S. in the bract

$€ 125$

B) Detailed T.S. in the bract

$€ 250$

C) Surface preparation of the upper epidermis of the bract

$€ 250$

D) Surface preparation of the lower epidermis of the bract

$€ 250$

coll.; collenchyma. cut.;cuticle. cys.; cystolithes of calcium carbonate. gl.h.; glandular hair. 1.epi.; lower epidermis. par.; parenchyma. ph.; phloem. raph.; raphides of calcium oxalate. st.gr.; starch granules. u.epi.; upper epidermis. v.b.; vascular bundle. w.p.; wood parenchyma. x.v.; xylem vessel. 
(10-14-17) $\mu$ in height. Stomata of the diacytic type are present on both surfaces measuring (44-62-82) $\mu$ in diameter. Cystolithes of calcium carbonate resembling those of leaf and stem are also present on both surfaces. Both epidermises show numerous glandular hairs, which are oval in shape, bi- or multicellular stalk and multicellular head of 4-6 cells, but those on the upper epidermis are sessile.

\section{The cortex}

It shows an upper and lower subepidermal collenchyma formed of one to two rows of thick-walled, nearly rounded cells. The rest of the cortical tissue is formed of nearly rounded, thin-walled parenchymatous cells, containing many starch granules which are spherical to ovoid in shape, mainly compound of two to three components, measuring (3- $\underline{6}-10) \mu$ in diameter. Scattered vascular bundles of the collateral type are present.

\section{The vascular tissue}

It consists of several vasocentric vascular bundles, where the phloem elements are formed of incomplete ring around the xylem. Phloem is formed of thin- walled soft elements. Xylem consists of lignified vessels, wood fibers and wood parenchyma. The vessels measure (10-15-19) $\mu$ in diameter. The wood fibers are formed of a nearly complete ring around the xylem vessels with thick walls, wide lumina and acute apices, measuring (340-420-490) $\mu$ in length and (1820-28) $\mu$ in diameter. The wood parenchyma consists of rectangular to subrectangular cells with lignified pitted walls, wide lumina and measure $(65-\underline{-70}-74) \cdot$ in length and (14-18-24) • in width.

\section{The calyx (Fig. 11A\&B)}

The transverse section in the sepal comprises upper and lower epidermises, enclosing inbetween a homogenous mesophyll, traversed by numerous vascular strands. The upper epidermis (Fig. 11C) is formed of polygonal elongated cells with straight anticlinal walls and smooth cuticle measuring $(24-32-52) \mu$ in length, (8-14-18) $\mu$ in width and (1822-28) $\mu$ in height.

The lower epidermis (Fig. 11D) is formed of elongated cells with straight to slightly wavy anticlinal walls and covered with thin smooth cuticle; they measure (26-35-55) $\mu$ in length, (6-10-14) $\mu$ in width and (1425-35) $\mu$ in height. The mesophyll is formed of upper and lower subepidermal collenchyma in addition to thin-walled, rounded parenchymatous cells containing starch granules measuring (2-7-15) $\mu$ in diameter, traversed lengthwise by numerous vascular strands, each is formed of cellulosic phloem and narrow xylem showing lignified vessels. Numerous scattered cystolithes of calcium carbonates stomata of the diacytic type, measuring (40-52-58) $\mu$ in diameter, numerous glandular hairs, of bi or multicellular stalk and multicellular head of 4-6 cells are present on the lower epidermis, while those on the upper epidermis are sessile. 

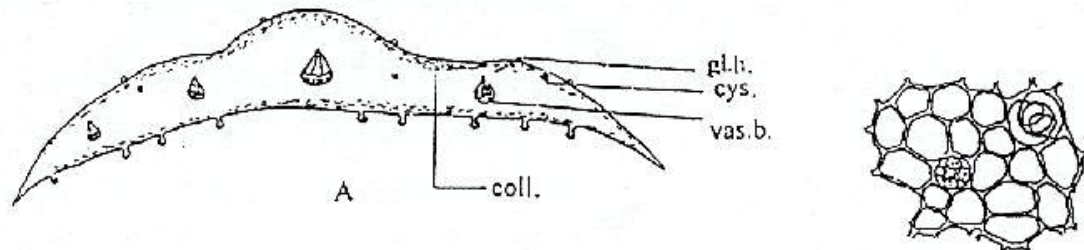

u. epi.

C
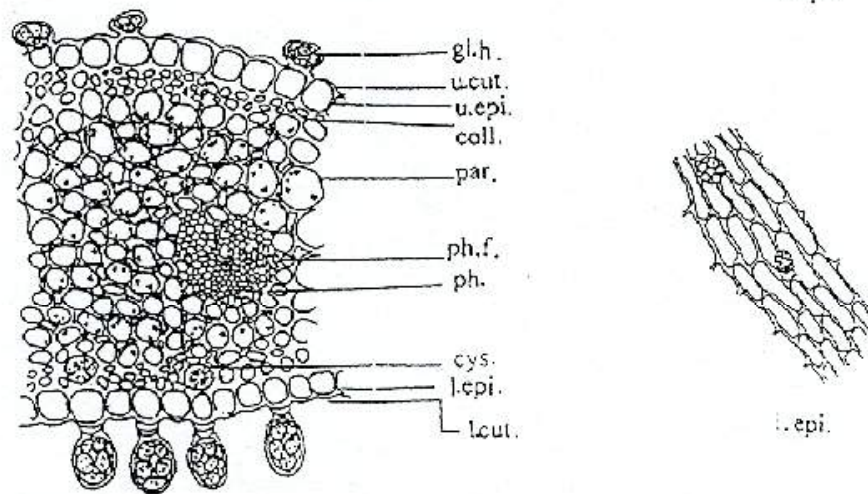

.epi

D

B

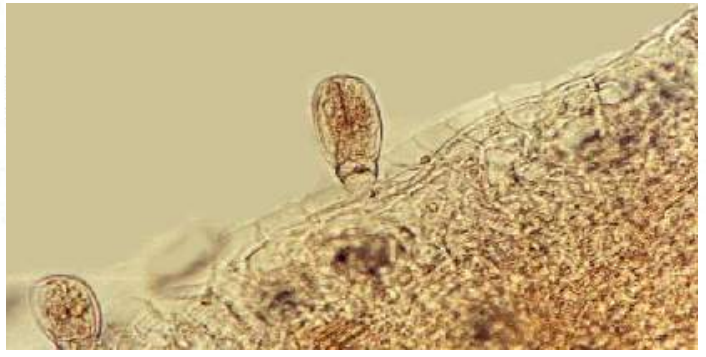

$\mathbf{E}$

Fig. 11:

A) Diagrammatic T.S. of the sepal

X 125

B) Detailed T.S. of the sepal

$\mathrm{X} 250$

C) Surface preparation of the upper epidermis of the sepal

$\mathrm{X} 250$

D) Surface preparation of the lower epidermis of the sepal

$\mathrm{X} 250$

E) Photo of the glandular hairs of the sepal

X 250

coll.; collenchyma. cut.;cuticle. cys.; cystolithes of calcium carbonate. gl.h.; glandular hair. 1.cut.; lower cuticle. l.epi; lower epidermis. par.; parenchyma. ph.f.; phloem fiber. st.gr.; starch granules. u.cut.; upper cuticle. u.epi; upper epidermis. vas.b.; vascular bundle. w.p; wood parenchyma. x.v; xylem vessel. 


\section{The corolla (Fig. 12A\&B)}

The transverse section in the petal shows upper and lower epidermises having radially elongated or columnar cells, enclosing inbetween a narrow parenchymatous homogenous mesophyll. The upper epidermal cells (Fig. 13A\&B\&C\&D\&F) at the apical region of the petal are polygonal with wavy anticlinal walls, usually papillosed measuring (40-66-110) $\mu$ in length and (22-41-65) $\mu$ in width. Those of the middle region of the petal are polygonal, axially elongated, with more wavy walls than those of the apical region and measure (50-7295) $\mu$ in length and (30-42-70) $\mu$ in width. Those of the basal region of the petal are axially elongated with slightly wavy anticlinal walls measuring (80-95-110) $\mu$ in length and (20-22-28) $\mu$ in width. They contain single and compound starch granules measuring (4-9-14) $\mu$ in diameter.

The lower epidermal cells at the upper and middle regions of the petal are pappillosed having wavy anticlinal walls, those of the basal region of the petal are also pappillosed but they are axially elongated with slightly wavy anticlinal walls. They resemble those of the upper epidermis in size. Both the upper and the lower epidermal cells are covered with thick, smooth cuticle. On both upper and lower epidermises, there are numerous nonglandular, uniserriate unicellular hairs.

\section{The androecium}

The transverse section in the anther (Fig. 14A\&B) shows two lobes attached by the connective; each anther lobe is formed of two pollen sacs containing pollen grains. The anther wall is thin, consisting of an epidermis followed by a fibrous layer. Numerous vascular bundles are also present. The epidermis is polygonal with straight anticlinal walls, covered with thin smooth cuticle measuring (40-56-65) $\mu$ in length, (36- $\underline{-53}-62) \mu$ in width and (44-58-72) $\mu$ in height. There are two types of hairs characteristic to the anther (Fig. 14A\&B).

The outer epidermis shows numerous nonglandular, uniserriate, multicellular hairs mainly of 2-4 elongated cells of warty surfaces; the terminal one is much larger with blunt end.

The inner epidermis shows few glandular hairs of bicellular stalk and a multicellular reniform head.

The fibrous layer of the anther is formed of one row of slightly lignified cells with bar-like thickened walls measuring (36-53-72) $\mu$ in length, (24-32-45) $\mu$ in width and (3247- 58) $\mu$ in height.

The pollen grains (Fig. 16) are spherical with strongly beaded exines, giving rise to a threads-like shape with three germ pores; two of them in one side, while the third being perpendicular to them. The pollen grain measures (60-76-90) $\mu$ in diameter. 


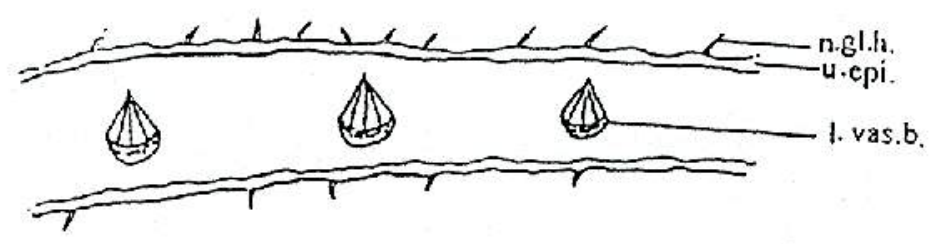

A

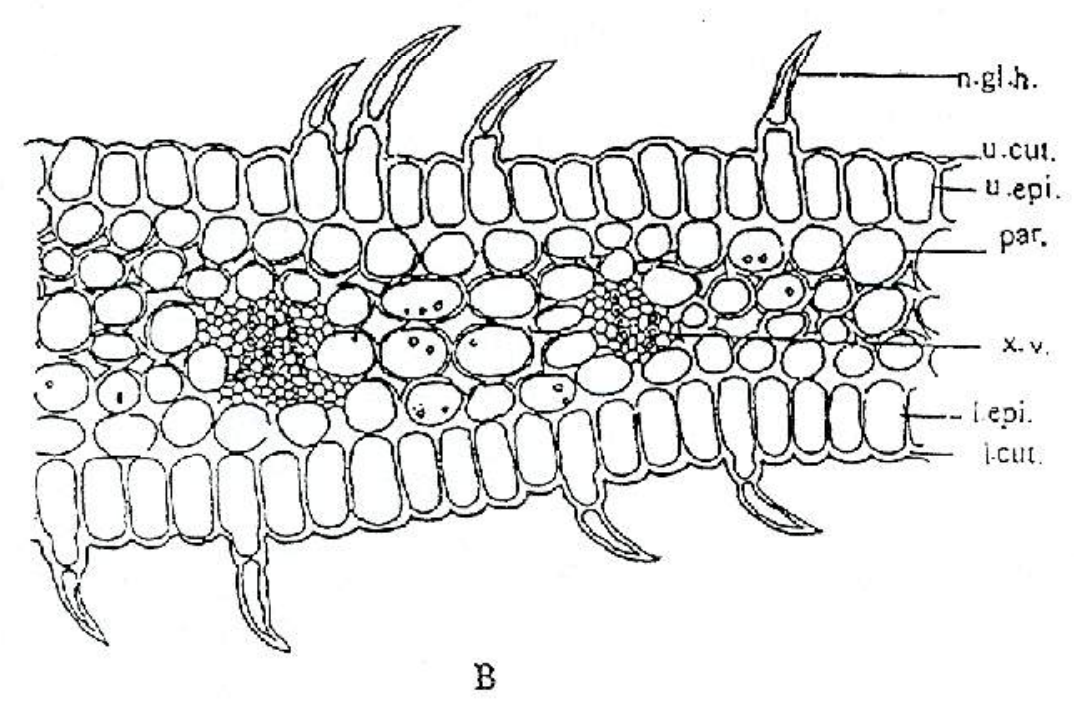

Fig. 12:

A) Diagrammatic T.S. in the petal

$€ 125$

B) Detailed T.S. in the petal

$€ 250$

1.cut.; lower cuticle. 1.epi.; lower epidermis. l.v.b.; lower vascular bundle. n.gl.h.; nonglandular hair. par.; parenchyma. u.cut.; upper cuticle. u.epi.; upper epidermis. x.v.; xylem vessel. 


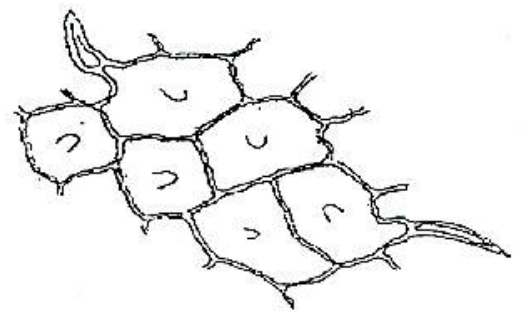

A

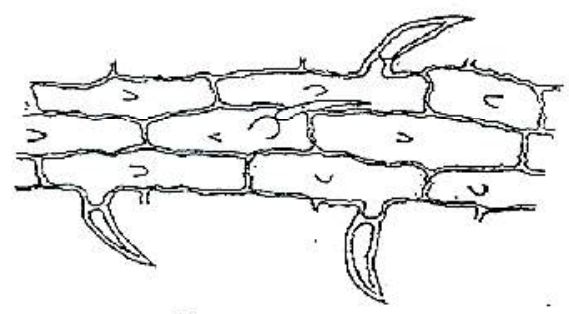

C

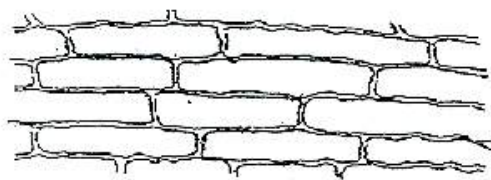

IS

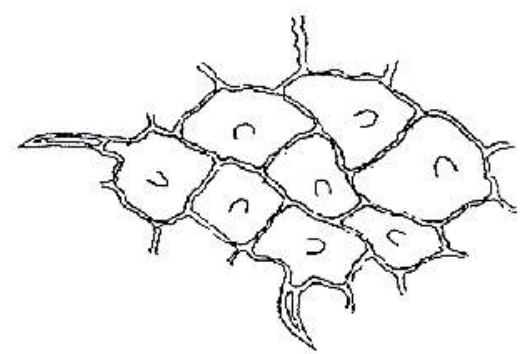

IS
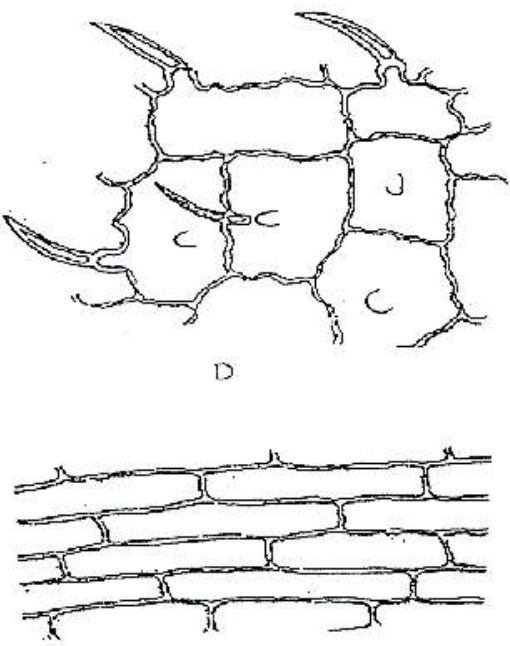

$€ 250$

€ 250

$€ 250$

$€ 250$

$€ 250$

$€ 250$ 


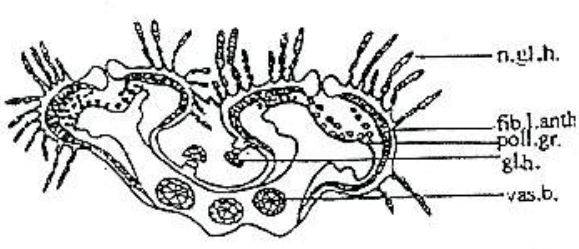

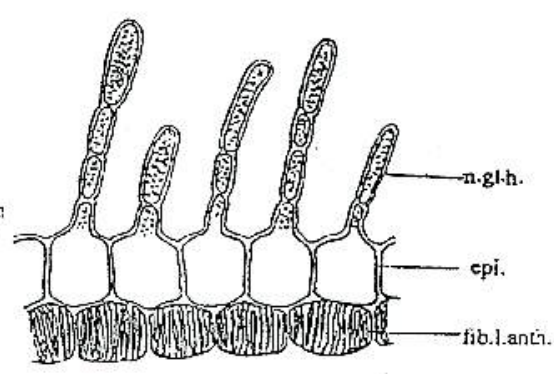

B

Fig. 14:

A) Diagrammatic T.S of the anther

$€ 125$

B) Detailed T.S of the anther

$€ 250$

epi.; epidermis. fib.l.anth.; fibrous layer of the anther. gl.h.; glandular hair. n.gl.l; non glandular hair. poll.gr.; pollen grain. v.b.; vascular bundle.

\section{The gynaecium}

The ovary

The transverse section in the ovary (Fig. 15A\&B) shows both upper and lower epidermises enclosing inbetween the ground tissue in which numerous vascular bundles are scattered. In surface view (Fig. 15C), the epidermal cells of the ovary appear polygonal with straight anticlinal walls covered with thick smooth cuticle and measure (20-2426) $\mu$ in length, $(14-\underline{16}-21) \mu$ in width, (22-35-46) $\mu$ in height.

\section{The style}

The surface preparation in the style (Fig. 15D) shows an epidermis of axially elongated cells with wavy anticlinal walls covered with smooth cuticle, measuring (56-90-151) $\mu$ in length and (10-16-25) $\mu$ in width and (32- $\underline{-10}-54) \mu$ in height.

\section{The stigma}

The surface preparation in the stigma (Fig. 15E) shows polygonal papillosed epidermal cells with smooth cuticle, measuring (14-18-25) $\mu$ in length, (10-16-24) $\mu$ in width and (16-18-22) $\mu$ in height.

\section{The powdered flower}

The powdered flower (Fig. 16) is yellowish-green in colour, with faint characteristic odour and a slightly bitter taste. It is characterized microscopically by:

1- Numerous unicellular nonglandular hairs of the petal.

2- Numerous pollen grains, spherical with warty or strongly beaded exines, giving rise to a threads-like appearance, mostly with three germ pores.

3- Fragments of the epidermal cells of the bract or the sepal, polygonal with straight or wavy anticlinal walls showing numerous glandular hairs, which are oval in shape, bi- or multicellular stalk and multicellular head of 4-6 cells. 
4- Numerous glandular hairs of uniand bicellular stalk and multicellular head of 4-6 cells, some of them being sessile. This type of hairs is characteristic to both bract and calyx.

5- Numerous nonglandular, uniserriate multicellular hairs of the outer epidermis of the anther mainly of 2-4 elongated cells of warty surfaces, the terminal one of which is much elongated with blunt end, in addition to few glandular hairs of the inner epidermis of the anther of bicellular stalk, multicellular reniform head.

6- Fragments of the epidermal cells of the petal, polygonal with wavy anticlinal walls; mostly papillosed.
7- Fragments of the anther, showing epidermal cells with straight anticlinal walls and covered with smooth cuticle, in addition to the slightly lignified cells of its fibrous layer.

8- Fragments of the epidermal cells of the ovary, polygonal with straight anticlinal walls and covered with thin, smooth cuticle.

9- Fragments of the epidermal cells of the style axially elongated with wavy anticlinal walls and covered with thin smooth cuticle.

10- Fragments of the papillosed epidermal cells of the stigma, polygonal with smooth cuticle. 


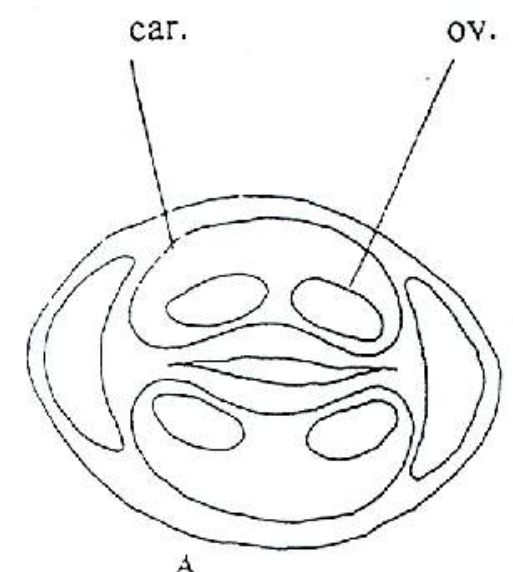

ov.

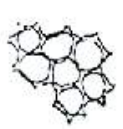

epi.ov.

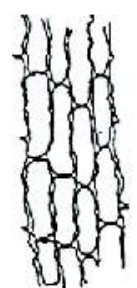

epi.sty.

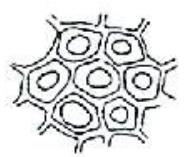

epi.siig.

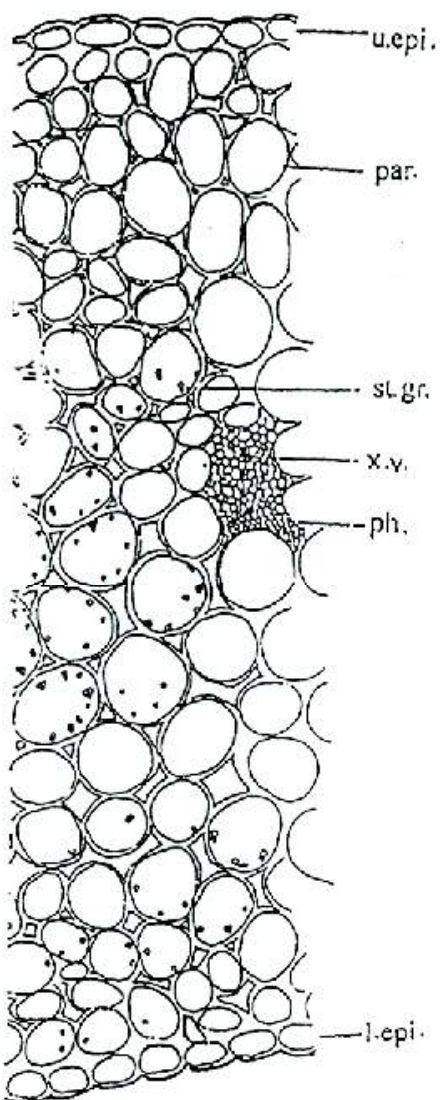

B

Fig. 15:

A) Diagrammatic T.S. of the ovary

X 125

B) Detailed T.S. in the ovary

$€ 187.5$

C) Surface preparation of the ovary

$€ 187.5$

D) Surface preparation of the style

$€ 187.5$

E) Surface preparation of the stigma

$€ 187.5$

car. carpels. epi.ov.; epidermis of the ovary. epi.stig.; epidermis of the stigma. epi.st.; epidermis of the style. 1.epi.; lower epidermis. ov. ovules. par.; parenchyma. ph.f.; phloem fiber. st.gr.; starch granules. x.v.; xylem vessel. 


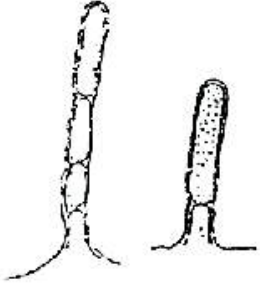

r.gl.h.

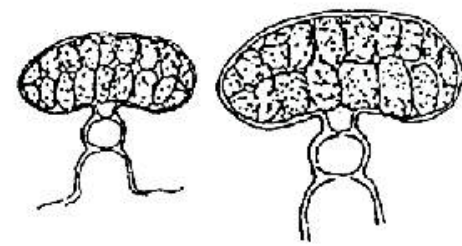

gl. h.

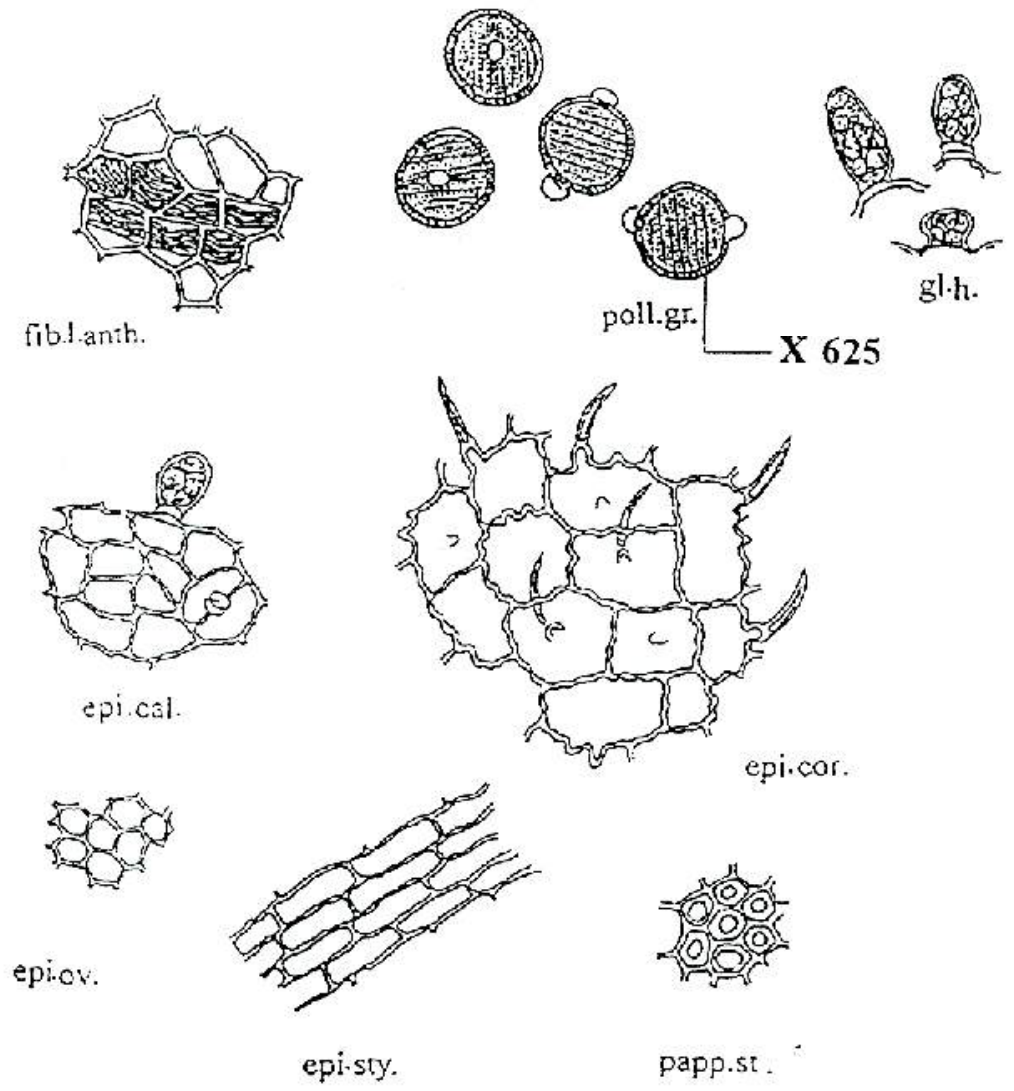

Fig. 16: The powdered flower

$€ 187.5$

epi.cal.; epidermis of the calyx. epi.cor.; epidermis of the corolla. epi.ov.; epidermis of the ovary. epi.stig.; epidermis of the stigma. epi.st.; epidermis of the style. fib.l.anth.; fibrous layer of the anther. gl.h; glandular hair. n.gl.h.; non glandular hair. papp.stig.; pappillosed stigma. poll.gr.; pollen grain. 


\section{REFERENCES}

1- G. E. Trease and W. C. Evans, ,Pharmacognosyf, $\quad 12^{\text {th }} \quad$ Ed., Baillere and Tindall Press, London, 1987, p. 35.

2- L. H. Bailey, ,The Standard Cyclopedia of Horticulturef, Vol. I, The MacMillan Co., New York, 1963, pp. 73-74.

3- K. R. Kirtikar, B. D. Basu and L. I. Colonel, ,Indian Medicinal Plantsf, Prakash Publisher, Delhi, 1975, p. 1861.

4- J. Hutchinson, ,The Families of Flowering Plantsf, Oxford, Clarendon Press $3^{\text {rd }}$ Ed., Vol. I, 1973, pp. 31, 151, 609.

5- R. Hegnauer and P. Kooiman, ,Planta Medicaf, 1978, p. 33.

6- T. Kanchanapoom, "Phenylpropanoide and Pheylethanoides from Acanthus ilicifolius", Ph.D thesis submitted to Institute of Pharmaceutical Sciences, Faculty of Medicine, Hiroshima University (2002).
7- T. Kanchanapoom, M.S. Kamel, R. Kasai, K. Yamasaki, C. Picheansoonthon and Y. Hiraga, Phytochemistry, 56, 369 (2001).

8- V. Tackholm, ,Students' Flora of Egypt $f, 2^{\text {nd }}$ Ed., Cairo University Press, Cairo, Egypt, 1974, p. 501.

9- C. R. Metcalfe and L. Chalk, ,Anatomy of Dicotyledons $f$, Vol. „, Clarendon Press, Oxford, 1972, p. 1014.

10- R. D. Gibbs, ,Chemotaxonomy of Flowering Plantsf, Vol. ," McGill-Queen's University Press, Montreal and London, 1974, p. 720. 